\title{
PERLINDUNGAN HUKUM TERHADAP ANAK JALANAN DALAM PRESPEKTIF HUKUM POSITIF DAN HUKUM ISLAM (Studi Kasus Pada Yayasan Madinatunajjah Kota Cirebon)
}

\author{
Sugianto \\ Fakultas Syariah Institut Agama Islam Negeri (IAIN) Syekh Nur Jati Cirebon \\ sugianto_lkbh@yahoo.co.id
}

\begin{abstract}
Abstrak
Number of street children in Indonesia has increased rapidly in recent years. An increasing number of street children is a growing social phenomenon that needs serious attention from various parties. Islam as a universal religion, it wants the children can live and grow properly. The goals of this papers is to elaboration the implementation of legal protection of street children in Foundation Madinatunnajjah Cirebon. The method used in this study are a normative juridical approach to determine the extent of law protect street children, and sociological juridical approach to see the protection effort not only in law but also in its implementation.

Jumlah anak jalanan di Indonesia mengalami peningkatan pesat dalam beberapa tahun belakangan. Peningkatan jumlah anak jalanan yang pesat merupakan fenomena sosial yang perlu mendapat perhatian serius dari berbagai pihak. Islam sebagai agama yang universal, sangatlah menghendaki agar anak-anak itu dapat hidup dan tumbuh berkembang secara baik. Tujuan dari pembahasan ini adalah untuk menentukan bagaimana bentuk perlindungan hukum terhadap anak jalanan di Yayasan Madinatunnajjah Cirebon. Metode yang digunakan dalam studi ini adalah normative yudisial untuk mengetahui sejauh mana hukum memberikan perlindungan kepada anak jalanan, dan sosiologi yuridis untuk melihat perlindungan bukan hanya dari aspek hukum tetapi juga aspek sosialnya.
\end{abstract}

Kata Kunci: Perlindungan, Hukum, Anak Jalanan

Pertumbuhan penduduk di kota besar di Indonesia saat ini sangat cepat, sehingga terdapat berbagai masalah yang cukup besar pula.Diantaranya masalah sosial, ekonomi, politik, budaya dan sebagainya. Salah satu masalah sosial yang sering kita jumpai di kota-kota besar adalah masalah anak jalanan yang keberadaannya seharusnya dipelihara oleh Negara sebagaimana bunyi Pasal 34 UUD 1945 yang menyatakan bahwa fakir miskin dan anak terlantar dipelihara oleh Negara. ${ }^{1}$

Anak terlantar dalam hal ini adalah

${ }^{1}$ Pipin Syaripin, Pengantar Ilmu Hukum, (Bandung: Pustaka Setia, 1999), h. 247. yang biasa kita sebut sebagai anak jalanan. Menurut Sandyawan pengertian anak jalanan adalah anak-anak yang berusia maksimal 16 tahun, telah bekerja dan menghabiskan waktunya di jalan. ${ }^{2}$ Sedangkan Peter Devis memberikan pemahaman bahwa fenomena anak-anak jalanan sekarang ini merupakan gejala global. Pertumbuhan urbanisasi dan membengkaknya daerah kumuh di kota-kota yang paling parah keadaannya adalah di Negara berkembang, telah memaksa sejumlah

${ }^{2}$ Rosdalina, "Aspek Keperdataan Perlindungan Hukum terhadap Anak Jalanan", Iqra', Vol.4 (Desember,2007), h. 71. 
anak semakin besar pergi kejalan ikut mencari makan demi kelangsungan hidup keluarga dan bagi dirinya sendiri. ${ }^{3}$ Sedang UNICEF membedakan anak jalanan menjadi dua, yaitu: children on the street dan children of the street. Anak jalanan yang termasuk kategori pertama adalah anak yang masih memiliki hubungan yang kuat dengan orang tuanya, sementara kategori yang kedua sudah tidak mempunyai hubungan yang erat dengan keluarganya. ${ }^{4}$

Jumlah anakjalanan di Indonesia mengalami peningkatan pesat dalam beberapa tahun belakangan. Pada tahun 1998, menurut data dari Kementrian Sosial, bahwa pernah terjadi peningkatan jumlah anak jalanan sekitar 400\%. Pada tahun 1999, pernah diperkirakan jumlah anak jalanan di Indonesia mencapai sekitar 50.000 anak dan $10 \%$ diantaranya adalah perempuan. Peningkatan jumlah anak jalanan yang pesat merupakan fenomena sosial yang perlu mendapat perhatian serius dari berbagai pihak. Perhatian ini tidak sematamata terdorong oleh besarnya jumlah anak jalanan, melainkan lebih penting bagaimana mencegah situasi dan kondisi kehidupan anak jalanan yang buruk.

\section{Peran Pemerintah Daerah/Lembaga terhadap Anak Jalanan.}

Pemerintah sebenarnya sudah menetapkan regulasi terkait upaya perlindungan anak, tentunya termasuk anakjalanan. Pada UndangUndang Perlindungan Anak Nomor 23 Tahun 2002 dinyatakan bahwa perlindungan anak adalah segala kegiatan untuk menjamin dan melindungi anak dan hak-haknya agar dapat hidup, tumbuh, berkembang, dan berpartisipasi, secara optimal sesuai dengan harkat dan martabat kemanusiaan, serta mendapat perlindungan dari kekerasan dan diskriminasi. ${ }^{5}$ Begitupula dalam UndangUndang Nomor 39 tahun 1999 tentang Hak

\footnotetext{
${ }^{3}$ Peter Davies, Hak-Hak AsasiManusia, (Jakarta: Yayasan Obor, 1994), h. 69.

${ }^{4}$ Abd Chayyi Fanani, Pesantren Anak Jalanan, (Surabaya: Penerbit Alpha,2008),h. 35.

${ }^{5}$ Pasal 1 Undang-Undang Republik Indonesia Nomor 23 Tahun 2002 tentang Perlindungan Anak
}

Asasi Manusia juga dinyatakan bahwa setiap anak berhak atas perlindungan oleh orang tua, keluarga, masyarakat dan Negara. Hak anak adalah hak asasi manusia dan untuk kepentingannya hak anak itu diakui dan dilindungi oleh hokum bahkan sejak dalam kandungan. ${ }^{6}$

Namun kenyataannya, anak jalanan mengalami perlakuan yang tidak manusiawi dan tidak hanya terbatas pada kekerasan fisik, seperti dipukul, ditendang, ditempeleng, bahkan dibunuh, serta kekerasan psikis, seperti dicemooh, dihardik, dibentak, tetapi juga merembet pada kekerasan seksual, seperti dicabuli dan diperkosa. Kita semua tentu teramat risau dengan pemberitaanpemberitaan media massa dewasa ini, tidak sedikit anak-anak kita, baik anak jalanan maupun yang bukan anak jalanan, yang menjadi korban kebiadaban nafsu syahwat bapak kandungnya, saudara kandungnya, guru sekolahnya, tetangganya, dan bahkan anak-anak seusianya. Selain itu, ada pula anak jalanan yang sengaja dieksploitasi, baik oleh orangtua kandung maupun oleh orang lain. Mereka dipekerjakan dalam sektor ekonomi produktif dengan jam kerja di luar batas kemampuan, bahkan menjadi korban trafficking yang dijadikan pekerja seks komersial(PSK). ${ }^{7}$

Akibat dari eksploitasi tersebut, mengakibatkan pertumbuhan mereka baik flsik, mental, spiritual, maupun sosial menjadi terhambat. Padahal menurut Pasal 4 Undang-Undang Perlindungan Anak Nomor 23 Tahun 2002, setiap anak berhak untuk dapat hidup, tumbuh, berkembang, dan berpartisipasi secara wajar sesuai dengan harkat dan martabat kemanusiaan, serta mendapat perlindungan dari kekerasan dan diskriminasi. Bahkan Anak jalanan yang seharusnya masih berada di sekolah, justru mereka malah menjalani kehidupan jalanan.

${ }^{6}$ Pasal 52 ayat (1) dan (2) Undang-Undang Republik Indonesia Nomor 39 Tahun 1999 tentang Hak Asasi Manusia

${ }^{7}$ www. Blogspot.Com.//Kumpulan Khutbah Jum'at Peduli Anak Jalanan, (Mataiam: Lembaga Perlindungan Anak NTB, 2004), Ed.1 
Kenyataan bahwa anak-anak jalanan tidak dapat mengakses pendidikan baik formal maupun non formal, termasuk pendidikan keluarga. Padahal sudah menjadi tugas orang tua untuk memberikan pendidikan dan perlindungan kepada anak-anaknya.

Islam sebagai agama yang universal, sangatlah menghendaki anak-anak itu dapat hidup dan tumbuh berkembang secara baik. Bahkan Islam memandang hakekat anak itu sebagai rahmat yang diberikan Allah SWT kepada hambanya yang harus dibina agar mereka tidak menjadi anak yang terlantar. Dalam hal ini Allah berfirman yang artinya: "Bukanlah kebaikan-kebaikan itu menghadapkan ke wajah kamu kearah titnur dan barat, tetapi kebaikan itu adalah barang siapa yang beriman kepada Allah, hari akhirat, malaikat-malaikat, kitab-kitab, nabi-nabl, dan memberikan harta yang dicintainya kepada para kerabat, anak-anak yatim, orang-orang miskin, musafir (yang membutuhkan pertolongan), orang-orang yang meminta-minta, dan membebaskan perbudakan, mendirikan salat, menunaikan zakat, dan orang-orang yang memenuhi janjinya bila mereka berjanji, dan orang-orang yang sabar dalam menghadapi kesempitan, penderitaan, dan pada waktu peperangan. Mereka itulah orangorang yang benar (imannya) dan mereka itulah orang-orang yang bertaqwa."

Keberpihakan Islam ini bukan sebatas pada aktivitas yang memecahkan berbagai masalah sosial dan kemanusian kaum dhuafa termasuk anak jalanan, melainkan lebih dari itu adalah bagaimana menyelamatkan mereka dari bahaya kesesatan dan kekafiran, kemudian membawa mereka menuju keselamatan, kedamaian, dan kebahagiaan di dunia dan akhirat.

Bertitik tolak dari posisi anak sebagai amanah yang harus dipenuhi kebutuhan dan hak-haknya sebagai anak, maka hak dasar mereka harus terpenuhi. Pemenuhan itu diwujudkan dalam merawat, menjaga, membesarkan, mendidik, membina, dan melindungi anak agar dapat tumbuh kembang secara optimal, baik secara fisik, mental, maupun sosial sehingga menjadi anak yang berkualitas, mempunyai akhlak yang mulia ${ }^{8}$ (QS.Al Baqarah[2]: 177) dan sejahtera lahir batin. ${ }^{9}$ Bahkan Allah melarang hambanya untuk menelantarkan keluarga, termasuk anak yang berada pada pengasuhannya. Allah berfirman yang artinya: "Dan hendaklah takut kepada Allah orang-orang yang seandainya meninggalkan dibelakang mereka anak-anak yang lemah (dhi'afan), yangmereka khawatir terhadap (kesejahteraan) mereka."10

Berdasarkan Pasal 3 Undang-Undang Nomor 23 Tahun 2002 dinyatakan bahwa perlindungan anak bertujuan untuk menjamin terpenuhinya hak-hak anak agar dapat hidup, tumbuh, berkembang, dan berpartisipasi secara optimal sesuai dengan harkat dan martabat kemanusiaan, serta mendapat perlindungan dari kekerasan dan diskriminasi, demi terwujudnya anak Indonesia yang berkualitas, berakhlak mulia, dan sejahtera. ${ }^{11}$ Namun dalam hal ini fakta menunjukkan lain terhadap kehidupan anak, terutama anak jalanan. Fenomena anak jalanan di Indonesia adalah masalah sosial yang kompleks. Hidup menjadi anak jalanan sesunggunya bukanlah merupakan pilihan yang menyenangkan, karena mereka berada pada kondisi yang tidak memiliki masa depan yang jelas. Keberadaan anak jalanan sering dianggap sebagai biang persoalan oleh berbagai pihak, mulai dari keluarga, masyarakat, dan Negara. Namun yang patut disayangkan adalah bahwa selama ini kita belum memberikan pehatian yang besar kepada mereka yang termarjinalkan.

Yayasan Madinatunnajjah di kota Cirebon adalah salah satu lembaga yang memberikan perhatian kepada anak-anak jalanan. Pada mulanya, Yayasan Madinatunnajjah hanyalah sebuah tempat komunitas belajar anak jalanan yang lokasinya berada di pinggiran terminal Harjamukti Kota Cirebon. Namun kemudian, Yayasan Madiantunnajjah telah ternyata mampu tumbuh dan berkembang sejak tahun 2001 sebagai cabang dari Yayasan Darunnajjah Jakarta. Upaya pembinaan anak jalanan dari pendekatan, misalnya melalui

\footnotetext{
${ }^{9}$ Ibnu Anshori, Perlindungan Anak Dalam Islam, (Jakarta, 2000.Cipta Karya), hlm.16.

${ }^{10}(\mathrm{QS}$. An Nisaa'[4]: 9).

${ }^{11}$ Pasal 3 Undang-Undang Republik Indonesia Nomor 23 Tahun 2002 Tentang Perlindungan Anak
} 
strategi belajar, berkarya, dan berdo'a yang dikemas secara unik dan menarik, pengelola yayasan berhadap dapat mengubah pola pikir dan perilaku anak jalanan yang sebagian besar adalah anak-anak putus sekolah bahkan tak pernah sekolah. Menurut penulis, sejak mulai berdiri hingga sekarang ada lebih dari 200 anak yang tersebar di berbagi tempat. Di Yayasan Madinatunnajjah, anak jalanan mendapatkan pelajaran pokok berupa wawasan seni dan budaya, budi pekerti, gaya hidup/ kepribadian, norma, dan pengetahuan agama, yang kemudian mereka praktikkan dalam kehidupan sehari-hari baik di lingkungan yayasan maupun di luar yayasan.

Dengan penuh kesabaran, keuletan, dan kepiawaian menggunakan berbagai pendekatan, pengurus Yayasan Madiantunnajjah mencoba membedah segala persoalan yang terlanjur melilit anak-anak miskin dan terlantar (anak jalanan) yang memang banyak berkeliaran di sudut Kota Cirebon. Bahkan dari kegigihan mereka, akhirnya pengurus dengan dibantu masyarakat yang peduli bisa mewujudkan harapannya yakni membangun sebuah tempat/ kelas Madrasah ${ }^{12}$ untuk belajar yang terletak di jalan Dukuh Semar Kota Cirebon. Melalui pendidikan yang dikembangkan, Yayasan Madinatunnajjah terbukti mampu merubah pola pikir anak jalanan yang selama ini sering dianggap beban masyarakat menjadi pribadi anak yang lebih santun, bersih, sehat, dan berbudaya.

\section{Definisi Anak}

Anak adalah generasi penerus masa depan bangsa. Keberadaan anak perlu mendapat jaminan hukum dari pemerintah. Ada beberapa regulasi yang terkait terminologi anak. Adapun perundang-undangan yang terkait dengan terminologi anak, yaitu: (a) Pasal 45 KUH

\footnotetext{
${ }^{12}$ Pondok Pesantren Madinatunnajah Kalimukti Cirebon didirikan pada tanggal 3 Pebruari 1988 $\mathrm{M}$ di atas tanah wakaf seluas 6,5 ha oleh Drs. KH. Mahrus Amin yang saat ini menjabat sebagai Ketua Yayasan Annajah. Pada awal berdirinya pesantren ini dikhususkan bagi santri yatim dan tidak mampu dari berbagai daerah di Indonesia. Lihat, http:// id.wikipedia.org/wiki/Madinatunnajah_Kalimukti_ Kab._Cirebon
}

Pidana adalah anak yang umurnya belum mencapai 16 (enam belas) tahun; (b) Pasal 330 KUH Perdata mengatakan, orang belum dewasa adalah mereka yang belum mencapai umur 21 (dua satu) tahun dan tidak lebih dahulu kawin; (c) Pasal I Ayat (1) Undang-Undang Perlindungan Anak Nomor 23 Tahun 2002, anak adalah seseorang yang belum berusia 18 (delapan belas) tahun, termasuk anak yang masih dalam kandungan; (d) Pasal 1 ayat (1) Undang-Undang Pengadilan Anak Nomor 3 Tahun 1997, anak adalah seseorang yang belum mencapai umur 18 (delapan belas) tahun dan belum pernah kawin; (e) Pasal 1 Ayat (2) Undang-Undang Kesejahteraan Anak Nomor 4 Tahun 1979, Anak adalah seseorang yang belum mencapai umur 21 (dua puluh satu) tahun; (f) Pasal 1 ayat (5) Undang-Undang Hak Asasi Manusia Nomor 39 Tahun 1999, Anak adalah setiap manusia yang berusia dibawah 18 (delapan belas) tahun dan belum menikah, termasuk anak yang masih dalam kandungan apabila hal tersebut adalah demi kepentingannya; (g) Pengertian Anak menurut Konvensi Tentang Hak-hak Anak (convention on the right of the child) tahun 1989 menyatakan bahwa Anak adalah setiap manusia dibawah umur 18 (delapan betas) tahun kecuali menurut undang-undang yang berlaku pada anak, kedewasaan dicapai lebih awal.

Diantara sekian banyak pengertian anak yang telah dikemukakan, maka dalam tulisan ini pengertian anak yang digunakan adalah pengertian anak menurut Undang-Undang Perlindungan Anak yaitu anak adalah seseorang yang belum berusia 18 (delapan belas) tahun, termasuk anak yang masih dalam kandungan. Dimana dalam undang-undang ini menjamin dan melindungi hak-hak anak agar dapat hidup, tumbuh, berkembang dan berpatisipasi secara optimal sesuai dengan harkat dan martabat kemanusiaan serta mendapat perlindungan dan kekerasan dan diskriminasi.

Ada beberapa pengertian anak jalanan menurut beberapa ahli hukum. Sandyawan memberikan pengertian bahwa anak jalanan adalah anak-anak yang berusia maksimal 16 tahun, telah bekerja dan menghabiskan 
waktunya di jalanan. Peter Davies memberikan pemahaman bahwa fenomena anak-anak jalanan sekarang ini merupakan suatu gejala global. Pertumbuhan urbanisasi dan membengkaknya daerah kumuh di kota-kota yang paling parah keadaannya adalah di negara berkembang, telah memaksa sejumlah anak yang semakin besar untuk pergi ke jalanan ikut mencari makan demi kelangsungan hidup keluarga dan bagi dirinya sendiri. ${ }^{13}$

\section{Kategorisasi Anak Jalanan}

Anakjalanan dapat dikelompokkan menjadi tiga macam, yaitu ${ }^{14}$ (1) Anak jalanan on the street/ road. Kategori anak jalanan on the street/road atau anak-anak yang ada di jalanan, hanya sesaat saja di jalanan, dan meliputi dua kelompok yaitu kelompok dari luar kota dan kelompok dari dalam kota; (2) Anak jalanan of the street/road. Kategori anak jalanan of the street/road atau anak-anak yang tumbuh dari jalanan, seluruh waktunya dihabiskan di jalanan, tidak mempunyai rumah, dan jarang atau tidak pernah kontak dengan keluarganya; (3) Vulnerable to be street children, yaitu kategori anak-anak jalanan yang berpotensi atau rentan menjadi anak terlantar. Artinya jika anak tidak diawasi dan dibina akan terlantar sehingga tidak menutup kemungkinan menjadi anak jalanan. Meskipun anak-anak ini masih mempunyai hubungan keluarga yang cukup kuat, tetapi hidup mereka terombang ambing dari satu tempat ketempat lain dengan segala resikonya.

Jika mengamati kehidupan anak-anak jalanan, tentu kita dapat mengenali karakteristik kehidupan mereka. Adapun karakteristik anak jalanan secara umum, yaitu: (1) Berada di tempat umum (jalanan, pasar, pertokoan, tempat hiburan) selama 3-24 jam sehari; (2) Berpendidikan rendah (kebanyakan putus sekolah, dan sedikit sekali yang tamat SD); (3) Kebanyakan berasal dari keluargakeluarga yang tidak mampu (kebanyakan

${ }^{13}$ J. Satrio, J, Hukum Pribadi Bagian I Persoon Alamiah, (Bandung Citra Aditya Bakti, 1999), h 17-23

${ }^{14}$ R.Soetojo Prawirohamidjojo \& Marthalena Pohan, Hukum Orang dan Keluarga, (Surabaya, Airlangga University Press, 2000), h. 322 kaum urban, dan beberapa di antaranya tidak jelas keluarganya); (4) Melakukan aktivitas ekonomi (melakukan pekerjaan pada sektor informal).

Karakteristik tersebut di atas adalah bersifat umum, sehingga bukan berarti bahwa fenomena anak jalanan merupakan fenomena yang tunggal. ${ }^{15}$ Penelusuran yang lebih empatik dan intensif ke dalam kehidupan mereka menunjukkan adanya keberagaman. Keberagaman tersebut antara lain terkait latar belakang keluarga, lamanya berada di jalanan, lingkungan tempat tinggal, pilihan pekerjaan, pergaulan, dan pola pengasuhan. Tidaklah mengherankan jika terdapat keberagaman pola tingkah laku, kebiasaan, dan tampilan dari anak-anak jalanan. ${ }^{7}$

Ada beberapa hal yang dapat menjadi penyebab munculnya fenomena anak jalanan, yaitu: (a) Sejumlah kebijakan makro dalam bidang sosial ekonomi telah menyumbang munculnya fenomena anak jalanan; (b) Modernisasi, industrialisasi, migrasi, dan urbanisasi menyebabkan terjadinya perubahan jumlah anggota keluarga dan gaya hidup yang membuat dukungan sosial dan perlindungan terhadap anak menjadi berkurang; (c) Kekerasan dalam keluarga menjadi latar belakang penting penyebab anak keluar dari rumah dan umumnya terjadi dalam keluarga yang mengalami tekanan ekonomi dan jumlah anggota keluarga yang besar; (d) Terkait permasalahan ekonomi sehingga anak terpaksa ikut membantu orang tua dengan bekerja di jalanan; (e) Orang tua "mengkaryakan" sebagai sumber ekonomi keluarga pengganti peran yang seharusnya dilakukan oleh orang dewasa.

Fenomena anak jalanan tentu perlu mendapat penangan secara serius, dikatakan demikian sebab anak-anak jalanan rentan terhadap tindakan kekerasan yang dapat menggangu dirinya, yaitu: (1) Kekerasan fisik, berupa penganiayaan, pelecehan, kecelakan lalu lintas; (2) Kekerasan nonfisik berupa stigma (penilaian negative masyarakat yaitu sebagai

\footnotetext{
${ }^{15}$ Peter Davies, Hak-hak Asasi Manusia, (Jakarta: Yayasan Obor, 1994), h. 69
} 
pelaku tindak kriminal). Disamping itu, anak-anak jalanan juga rentan terhadap perlakukan seperti: penangkapan, penggusuran/ pengusiran, pemaksaan sesama anak jalanan, perampasan barang serta juga, pemerasan/ pengkompasan. ${ }^{16}$

Perlakuan salah yang rentan diterima oleh anak jalanan dapat dikategorikan pada pengaruh dan sifat-sifatnya, yaitu: (1) Perlakuan salah secara fisik, yaitu suatu perlakuan yang terjadi ketika anak dengan sengaja disakiti atau ditempatkan pada kondisi yang memungkinkan disakiti secara fisik yang dapat diketahui dari beberapa indikator umumnya termasuk memar, luka bakar, sobekan atau gigitan, dan lain-lain; (2) Perlakuan salah secara mental (mental abuse), yaitu setiap tindakan baik sengaja maupun tidak sengaja yang dilakukan oleh orang lain sehingga membuat seseorang individu sakit atau terganggu perasaannya atau membuat memperoleh perasaan tidak enak. Oleh karena itu tindakan ini juga mencakup tindakan yang menyangkut kekerasan secara fisik dan psikis yang diartikan sebagai tindakan yang tidak melukai fisik tetapi perasaan yang terluka atau marah, sedih, jengkel, kecewa, takut; (3) Perlakuan salah secara seksual. Istilah perlakuan salah secara seksual misalnya: "any sexsual activity with someone who is not legally competent to give consent or has refused consent". Definisi tersebut meliputi kegiatan seksual pada segala umur dengan keluarga dekat seperti ayah dan anak (incest).

\section{Perlindungan Hukum Anak Jalanan}

Hal penting yang perlu diperhatikan dalam peraturan perundang-undangan yang berkaitan dengan anak adalah konsekuensi penerapannya dikaitkan dengan berbagai faktor seperti kondisi ekonomi, sosial politik, dan budaya masyarakat. Dalam berbagai peraturan perundang-undangan terdapat perbedaan ketentuan yang mengatur tentang anak, hal ini dilatarbelakangi berbagai faktor yang merupakan

${ }^{16}$ Tata Sudrajat, Anak Jalanan dan Masalah Seharihari Sampai Kebijaksanaan,(Bandung Yayasan Akatiga, 1996), h. 151-152 prinsip dasar yang terkandung dalam dasar pertimbangan dikeluarkannya peraturan perundang-undangan yang bersangkutan yang berkaitan dengan kondisi dan perlindungan anak.

Kedudukan anak sebagai generasi muda yang akan meneruskan cita-cita luhur bangsa, caloncalon pemimpin bangsa di masa mendatang dan sebagai sumber harapan bagi generasi terdahulu, perlu mendapat kesempatan seluas-luasnya untuk tumbuh dan berkembang dengan wajar baik secara rohani, jasmani, dan sosial. Perlindungan anak merupakan usaha dan kegiatan seluruh lapisan masyarakat dalam berbagal kedudukan dan peranan, yang menyadari betul pentingnya anak bagi nusa dan bangsa di kemudian hari. Jika mereka telah matang pertumbuhan fisik maupun mental dan sosialnya, maka tiba saatnya menggantikan generasi terdahulu.

Perlindungan anak adalah segala usaha yang dilakukan untuk menciptakan kondisi agar setiap anak dapat melaksanakan hak dan kewajibannya demi perkembangan dan pertumbuhan anak secara wajar baik secara fisik, mental, maupun sosial. Perlindungan anak merupakan perwujudan adanya keadilan dalam suatu masyarakat. dengan demikian perlindungan anak diusahakan dalam berbagai bidang kehidupan bernegara dan bermasyarakat. Kegiatan perlindungan anak membawa akibat hukum, baik dalam kaitannya dengan hukum tertulis maupun hukum tidak tertulis. Hukum merupakan jaminan bagi kegiatan perlindungan anak. Arif Gosita mengemukakan bahwa kepastian hukum perlu diusahakan demi kelangsungan kegiatan perlindungan anak dan mencegah penyelewengan yang membawa akibat negatif yang tidak diinginkan dalam pelaksanaan perlindungan anak. ${ }^{17}$

Perlindungan anak tidak boleh dilakukan secara berlebihan dan memperhatikan dampaknya terhadap lingkungan maupun diri anak itu sendiri, sehingga usaha perlindungan yang dilakukan tidak berakibat negatif. Perlindungan anak dilaksanakan rasional, bertanggung

\footnotetext{
${ }^{17}$ Arif Gosita, Masalah Perlindungan Anak, (Jakarta Akademi Pressindo, 1989), h. 35
} 
jawab dan bermanfaat yang mencerminkan suatu usaha yang etektif dan efisien. Usaha perlindungan anak tidak boleh mengakibakan matinya inisiatif, kreatifitas, dan hal-hal lain yang menyebabkan ketergantungan kepada orang lain dan berperilaku tak terkendali, sehingga anak tidak memiliki kemampuan menggunakan hak-haknya dan melaksanakan kewajiban-kewajibannya. Perlindungan anak dapat dibedakan dalam 2 (dua) bagian yaitu sebagai berikut: (a) Perlindungan anak yang bersifat yuridis, yang meliputi perlindungan dalam bidang hukum publik dan dalam bidang hukum keperdataan; (b) Perlindungari anak yang bersifat non yuridis, yang meliputi perlindungan dalam bidang sosial, bidang kesehatan, bidang pendidikan.

Pasal 1 Angka 2Undang-Undang Perlindungan Anak Nomor 23 Tahun 2002 menegaskan bahwa perlindungan anak adalah segala kegiatan untuk menjamin dan melindungi anak dan hak-haknya agar dapat hidup, tumbuh, berkembang, dan berpartisipasi. Secara optimal sesuai dengan harkat dan martabat kemanusiaan, serta mendapat perlindungan dan kekerasan dan diskriminasi. Perlindungan anak dapat juga diartikan sebagai segala upaya yang ditujukan untuk mencegah, rehabilitasi, dan memberdayakan anak yang mengalami tindak perlakuan salah (child abused), eksploitasi, dan penelantaran, agar dapat menjamin kelangsungan hidup dan tumbuh kembang anak secara wàjar, baik fisik, mental, dan sosialnya.

Arif Gosita berpendapat bahwa perlindungan anak adalah suatu usaha untuk melindungi anak agar dapat melaksanakan hak dan kewajibannya. ${ }^{18}$ Perlindungan hak-hak anak pada hakikatnya menyangkut langsung pengaturan dalam peraturan perundangundangan. Kebijaksanaan, usaha dan kegiatan yang menjamin terwujudnya perlindungan hak-hak anak, pertama-tama didasarkan atas pertimbangan bahwa anak-anak merupakan golongan yang rawan dan dependent, disamping karena adanya golongan anak-anak yang mengalami hambatan dalam pertumbuhan dan perkembangannya, baik rohani, jasmani

${ }^{18}$ Ibid., h. 52 maupun sosial.

Perlindungan anak bermanfaat bagi anak dan orang tuanya serta pemerintahnya, maka koordinasi kerjasama perlindungan anak perlu diadakan dalam rangka mencegah ketidakseimbangan kegiatan perlindungan anak secara keseluruhan. Sehubungan dengan hal ini, Abdul Hakim Garuda Nusantaran mengatakan: "Masalah perlindungan hukum bagi anak-anak merupakan satu sisi pendekatan untuk melindungi anak-anak Indonesia. Masalahnya tidak semata-mata bisa didekati secara yuridis, tapi perlu pendekatan lebih luas, yaitu ekonomi, sosial, dan budaya."19

Dasar pelaksanaan perlindungan anak adalah sebagai berikut: (1) Dasar filosofis, yaitu pancasila sebagai dasar kegiatan dalam berbagai bidang kehidupan keluarga, bermasyarakat, bernegara, dan berbangsa, serta dasar filosofis pelaksanaan perlindungan anak; (2) Dasar etis, yaitu pelaksanaan perlindungan anak harus sesuai dengan etika profesi yang berkaitan, untuk mencegah perilaku menyimpang dalam pelaksanaan kewenangan, kekuasaan, dan kekuatan dalam pelaksanaan perlindungan anak; (3) Dasar Yuridis ; pelaksanaan perlindungan anak harus didasarkan pada UUD 1945 dan berbagai peraturan perundang-undangan Iainnya yang berlaku. Penerapan dasar yuridis ini harus secara integratif, yaitu penerapan terpadu menyangkut peraturan perundangundangan dari berbagai bidang hukum yang berkaitan.

\section{Kesimpulan}

Yayasan Madinatunnajjah adalah sebuah lembaga yang mempunyai peran besar dalam pemeliharaan dan perlindungan anak, khususnya dalam pemeliharaan anak jalanan di Kota Cirebon, baik dari segi moral, pendidikan, etika, keterampilan, dan pembelajaran lainnya. Baik hukum positif maupun hukum Islam mendefinisikan anak sebagai seseorang yang belum berumur 18 tahun atau belum baligh, sehingga anak harus dilindungi. Bentuk

${ }^{19}$ Bagong Suyanto, Pelanggaran Hak dan Perlindungan Sosial Bagi Anak Rawan, (Surabaya Airlangga University Press, 2003), h. 22 
perlindungan terhadap anak dijamin dalam Undang-Undang Nomor 23 Tahun 2002 yang menyatakan bahwa perlindungan anak itu menjadi tanggungjawab kita bersama baik itu Negara maupun masyarakat disekitarnya, termasuk dalam hal ini terkait pemeliharaan anak jalanan. Upaya perlindungan terhadap anak merupakan suatu keniscayaan sebagaimana

\section{DAFTAR PUSTAKA}

Adi, Rianto, Metodologi Penelitian Sosial Dan Hukum, Jakarta: Penerbit Granit, 2004

Anshori, Ibnu, Perlindungan Anak Dalam Islam, Jakarta: Cipta Karya, 2000

Arikunto, Suharsimi, ProsedurPenelitian, Jakarta: Rineka Cipta, 1997

Al-Faruqi, Isma'il R., Altar Budaya Islam, Menjelajah Kazanah Peradaban Gemilang, Bandung: Mizan, 2003

Anshar, Maria Ulfa dan Mukhtar al-Shodiq, Pendidikan dan Pengasuhan Anak, (dalam Perspektif Gender), Jakarta: PT.Gramedia Pustaka Utama, 2005

Davies, Peter, Hak-Hak AsasiManusia, Jakarta: Yayasan Obor, 1994

Echols, John M. - Hasan Shadily, Kamus Inggris-Indonesia, Jakarta: Gramedia, 1992

Fuaduddin, Pengasuhan Anak Dalam Islam, (Jakarta: Lembaga Bagian Agama dan Jender, Solidaritas Perempuan dan The Asian Foundation, 1999

Husein, Abdur Rozak, Hak dan Pendidikan Dalam firman Allah dalam surat al-Baqarah Ayat 177. Sebagai tindak lanjut, pemerintah Kota Cirebon mendukung penuhi upaya Yayasan Madinatunnajjah untuk menjalankan visinya memberikan perlindungan kepada anakjalanan, bahkan siap memberikan sangsi tegas apabila komitmen tersebut dilanggarnya.

Islam, alih bahsa H. Azwir Butun Bandung: Fikahati Aneska, 1992

Himpunan Peraturan PerUndang-Undangan, Bandung: Fokus Media, 2007

Halim, M. Nipan, Anak Saleh Dambaan Keluarga, Yogyakarta: Mitra Pustaka, 2001

Musthoffa, Aziz, Untaian Mutiara Buat Keluarga, Yogyakarta: Mitra Pustaka, 2003

Prinst, Darwin, Hukum Anak Indonesia,Bandung: Aditya Bakti, 2003

Syamsudin, M., OperasionalisasiPenelitian Hukum, Jakarta: PT. Raja Grafindo Persada, 2007

Syaripin, Pipin, Pengantar Ilmu Hukum, Bandung: Pustaka Setia, 1999

Rosdalina, Aspek Keperdataan Perlindungan Hukum terhadap Anak Jalanan, Iqra', vol.4 Desember,2007

Undang-Undang Republik Indonesia Nomer 23 tahun 2002 Tentang Perlindungan Anak

Undang-Undang Republik Indonesia Nomor 3 Tahun 1997 Tentang Peradilan Anak 